\title{
Research on the Reform of Civil Engineering Professional Training Mode
}

\author{
Hua Luo \\ Nanchang Institute of Technology \\ Nanchang, China \\ 705413069@qq.com
}

\author{
Hua Chen \\ Nanchang Institute of Technology \\ Nanchang, China \\ 393071357@qq.com
}

\begin{abstract}
Based on the analysis of the historical evolution, the reform motivation and the status quo of the personnel training mode of civil engineering in our country, this paper analyzes the current personnel training mode of civil engineering in our country, and puts forward the reform of personnel training mode of civil engineering specialty in our country Problems, and put forward five proposals for the reform of personnel training mode of civil engineering for the existing problems in the reform of talent mode.
\end{abstract}

Keywords-Civil engineering; personnel training mode; teaching reform; modular curriculum system

\section{INTRODUCTION}

Since recent period, the state's investment in fixed assets has been maintaining a fairly large scale, resulting in a demand for more qualified personnel. Colleges and universities have set up civil engineering specialty one after another. Under the circumstances of enrollment expansion in colleges and universities, the enrollment of general colleges and universities is rapidly expanding, and the demand for undergraduates of civil engineering has been greatly improved. However, due to the inflated development, civil engineering colleges and universities also face a series of serious problems: The enrollment of higher education leads to the decline of the quality of students and the enormous pressure of employers on the huge employment pressure caused by the increase of graduates.

Higher education personnel training mode does not match the needs of society has caused the current college students create employment difficulties, corporate enrollment is an important reason. There are many kinds of personnel training modes for civil engineering in domestic colleges and universities, with the combination of historical evolution and realistic transformation. The training of talents in colleges and universities needs to be constantly changing with the development of social needs. However, the changes in training model for higher education still have some lag, resulting in some differences between the training of college graduates and the needs of society ${ }^{[1]}$.

Therefore, based on the historical evolution of reform in personnel training mode, the motivation of reform and the status quo of personnel training mode, this paper analyzes the current training mode of civil engineering talents in our country. In the light of the existing problems in the reform of talent

This work was financially supported by the Jiangxi teaching Reform and Researching Program of Higher Education(JXJG-15-25-2). mode, some suggestions are put forward to reform the training mode of civil engineering professionals.

\section{CIVIL ENGINEERING PROFESSIONAL PERSONNEL TRAINING MODE REFORM}

Civil engineering for the purpose of cultivating engineering national construction required excellent senior engineering and technical personnel, the professional is not only practical, but also relates to the field of engineering disciplines, wide range, high requirements for students of coordination, organization, management and decision-making ability, with the rapid development of science and technology and global economic integration. The industry of civil engineers international vision and international competitiveness are increasingly high requirements ${ }^{[2]}$.

\section{A. Talent training mode}

The concept of "talent cultivation mode" has been widely accepted by experts and scholars so far that there is no generally accepted definition of the definition of "talent cultivation mode". It is issued by the Ministry of education in 1998 on deepening the reform of teaching and training highquality talents to meet the needs of twenty-first Century:" Talent training mode is the knowledge, ability, quality structure and the way to realize this kind of structure that the school constructs for the student ${ }^{[3]}$, it has fundamentally stipulated the talent characteristic and embodied the education thought and the education idea centrally."

\section{B. Historical evolution of civil engineering professionals}

According to the development course of civil engineering specialty, the historical evolution of civil engineering talents training mode in China can be divided into three stages:

The first stage: from the middle of nineteenth Century to the middle of twentieth Century, the engineering education in our country has adopted the talent training mode of the western developed countries, the general education mode, which focuses on broadening the knowledge of the students and cultivating a solid and knowledge-based generalist.

The second stage: from the middle of twentieth Century to the end of twentieth Century, the training mode of Chinese colleges and universities to the Soviet Union to learn from the Soviet Union "special education".

The third stage: twenty-first Century, the trend of economic globalization has brought tremendous pressure to the China 
higher education, the cultivation of students from special education mode to "return" educational mode, compound talents is currently training ".

According to the course of development of civil engineering, we have gone through the historical transformation of "generalist-specialist-generalist" for the training mode of civil engineering talents in our country, As an applied specialty, civil engineering has its professional reform process mainly influenced by the demand of society. With the change of social needs, civil engineering is adjusted to meet the needs of socialist development to train qualified civil engineers.

\section{Reasons for the reform of civil engineering professional training mode}

From the historical evolution of civil engineering professionals training mode reform, the reasons for its reform are mainly the following aspects ${ }^{[4]}$.

The first is the ever-changing influence of the international environment. First of all, it is a concept of innovation. Now, many of our universities have learned some advanced ideas from foreign countries in the concept of talent training. Secondly, the new knowledge and technology that have been changing in the world are becoming more and more challenging to the related major of our country.

Second, the needs of social and economic development in China. From the perspective of industrial structure, civil engineering as an important livelihood industry for social production and development, from a single building to the present road, bridge, municipal and subway construction, put forward higher requirements for the knowledge, quality and ability of talents.

Third, the development needs of colleges and universities in our country.

With the popularization of higher education, the quality of talent has become increasingly prominent. Facing the dual pressures of international and domestic, how to cultivate highquality talents in colleges and universities has become a difficult and key issue for the development of colleges and universities. That is, the reform of personnel training mode is to meet the needs of our own colleges and universities.

\section{Problems in the reform of the training mode of civil engineering professionals}

The reform of China's civil engineering talent training mode is still under exploration and pilot stage and there are many problems and shortcomings including the following aspects $^{[5-6]}$ :

1) The training goal is divorced from reality and lack of consideration for the orientation of the school itself

Many colleges and universities improve the state of the talents training goal of "assimilation" with many of the transformative initiatives. However, the talents cultivation target is unrealistic away from the actual position of colleges and universities.
2) The curriculum setting is not matched with the training objectives and the curriculum setting is not reasonable

There are two more embarrassing situations in the curriculum: one is that the curriculum does not reflect the content of the goal of personnel training. The curriculum is still in accordance with the old system to continue teaching and do not make the appropriate adjustments; the second is the curriculum highlights the school professional advantages to show the characteristics of professional training but training objectives but do not have the corresponding statement.

3) The teaching method is backward and the teaching quality evaluation method of teachers needs to be improved

Most colleges and universities civil engineering courses use the traditional big class teaching mode. Teaching methods and learning methods is single. In this case, research teaching can only become a slogan. Teachers' teaching evaluation mainly involves three levels of schools, teachers and students. Few colleges and universities have included the evaluation of society and enterprises into the teaching evaluation system of teachers. This evaluation method is like "behind closed doors", it is difficult to determine whether the method of teaching can cultivate talents needed by the social, enterprises.

4) The teacher lacks engineering background and the construction of the teacher team is not sound

Teachers in colleges and universities is generally "college" to "university", is grown up from the traditional personnel training mode of doctoral or master's. Then the corresponding engineering practice experience (work experience) cannot meet the requirements and lacks the practical engineering background.

5) The university-enterprise cooperation education is difficult to promote and there is no effective guarantee mechanism

The university-enterprise cooperation education is a hot topic of education reform in recent years. Most of them are research universities such as "211" and "985", which are difficult to promote. Colleges and universities that have already conducted cooperative teaching mode of school enterprises lack legal guarantee.

\section{E. Suggestions on reform of the training mode of civil engineering professionals}

1) Colleges and universities make clear their own positioning and rationally customize talents training objectives

Colleges and universities are clearly positioning themselves to promote the certification of civil engineering. According to the professional certification standard to establish the target system of professional talents training. One is whether the target of talent cultivation meets the needs of society. The second is to ensure the scientific nature and rationality of professional training goals; Third, whether the target implementation of talents training is qualified, the school should ensure that the basic software and hardware facilities of the training target are realized. 
2) The curriculum should be scientific and rationalized and strengthen the construction of modular curriculum system

The selection and setting of curriculum is the form of professional training target. First, in the selection of textbooks, schools should focus on selecting textbooks jointly with stakeholders (government, enterprises, etc.) to ensure that textbook knowledge can keep abreast of social needs. Second, establish a modular curriculum system. The major courses of civil engineering are basic courses, introductory courses, professional courses, guiding courses and practical courses. Thirdly, the curriculum development mechanism should be established to strengthen the assessment of the curriculum system by outside professionals.

3) Update education and teaching methods, improve teaching evaluation methods

Updating education and teaching methods can not only be manifested in the classroom, should be run through the entire process of education and teaching. Teaching in small classes, teaching and research integration measures, teachers should focus more on practical measures; evaluation of teachers teaching, colleges and universities should be clear that the main teaching evaluation of teachers, that is, universities, employers (government, enterprises), education and teaching evaluation agencies, teachers, students.

4) Strengthen the construction of teachers, improve the ability of teachers

On how to strengthen the construction of teachers and improve teachers' ability to work, we can start from the following three aspects: First of all, colleges and universities encourage teachers stationed in enterprises for internships and exercises. Secondly, actively invite enterprise engineers to school lectures. Finally, increase the recruitment of part-time teachers.

5) Actively build government, schools, business cooperation and development platform

The cooperation and development platform of government, school and enterprise is a kind of sublimation of "schoolenterprise cooperation" mode that scholars generally talk about at present, building a platform for government, school and enterprise cooperation and development.

\section{CONCLUSIONS}

Based on the analysis of existing personnel training mode of civil engineering, this paper puts forward five suggestions on the feasible reform, but it still needs the solution of colleges and universities through continuous practice. It is a long process.

Through the research in this article, we can draw the following conclusions:

1)Analyzed the current status of personnel training mode in civil engineering, find out the existing problems in personnel training mode.

2)Put forward five suggestions: clear position and customize talents training objectives; scientific and rationalized constrict modular curriculum system; update teaching methods and improve teaching evaluation methods; Strengthen the construction of teachers and improve the ability of teachers; actively build cooperation and development platform of government, schools and business.

\section{REFERENCES}

[1] Wang Wenzhong. Reform and Practice of Practical Teaching of Civil Engineering Major in Local Universities [J] .Journal of Higher Education in China, 2004 (10)

[2] Zhao Yongping, WU He, CAO Xiaoyan. Innovation and Practice of Applied Undergraduate Talents Training System in Civil Engineering [J] .Journal of Chinese University, 2004 (05)

[3] Feng Xiang. Research on the Reform of Talents Cultivation Mode in China [D]. South Central University for Nationalities, 2015, 05

[4] Tan Juhua. Research on the Reform of Talents Cultivation in Higher Education in China - Based on the Perspective of Employment of College Students [J]. Wuhan University, 2014, 05

[5] Yu Weijian, Zhuang Xuezhen. Exploration of Training System of Innovative Talents in Civil Engineering [J]. Education and Careers, 2004 (14)

[6] Yuan Jianbo, Zheng Jianlong. Risks and Countermeasures in the Development of Civil Engineering [J] .China Higher Education Research, 2003 (06) 